\title{
Screening for FXI Deficiency (FXID) in Gaolao Cattle
}

\author{
S. J. Komatwar*, R. J. Zende, B. N. Ramteke, S. H. Dalvi, \\ R. S. Deshmukh and M. P. Sawane \\ Department of Animal Genetics and Breeding, Mumbai Veterinary College, \\ Parel, Mumbai-12, India \\ *Corresponding author
}

\section{A B S T R A C T}

\begin{tabular}{l} 
Ke y w o r d s \\
$\begin{array}{l}\text { FXID, Genetic } \\
\text { disorders, } \\
\text { Polymerase Chain } \\
\text { Reaction }\end{array}$ \\
\hline Article Info \\
$\begin{array}{l}\text { Accepted: } \\
\text { 04 December } 2020 \\
\text { Available Online: } \\
\text { 10 January 2021 }\end{array}$ \\
\hline
\end{tabular}

\begin{abstract}
The present study was carried out with an objective to find out most important autosomal recessive disorders in Gaolao cattle. Factor XI deficiency is one of the most important monogenic recessive disorder which causes prolonged bleeding, anemia, greater prevalence of repeat breeding or even lower resistance to pneumonia, mastitis and metritis resulting in reduced reproductive performance and increased susceptibility to disease. The only way to avoid economic losses is through an early detection of carriers. A total of 50 blood samples of Gaolao bull were collected from Gaolao bull mother farm, Hetikundi village of Wardha, Pohara farm of Amravati District and frozen semen lab, Nagpur of Maharashtra State. DNA extraction was done by using Phenol Chloroform Isoamyl Alcohol method. The isolated DNA was subjected for the quality and quantity with the help of gel electrophoresis and Nanodrop respectively. Then best quality DNA was selected for the Polymerase Chain Reaction. All the animals in present study showed only $244 \mathrm{bp}$ band suggesting non occurrence of FXID gene in the studied population.
\end{abstract}

\section{Introduction}

There are several genetic disorders in cattle amongst which few are most important for the reproductive and productive performance of the cattle. Mainly five disorders; BLAD (Bovine Leukocyte Adhesion deficiency), DUMPS (Deficiency of Uridine Monophosphate Synthase), Bovine Citrullinaemia, CVM (Complex Vertebral Malformation) and Factor XI (FactorXI deficiency syndrome), are being screened in Indian Cattle with the major objective to reduce the incidence of genetic disorders in cattle population and reduce economic losses to the farms. The occurrence of FXID was supported by many research workers in indigenous cattle and buffaloes.

In Factor XI (FXID) several number of proteins involved in blood clotting mechanism. It is inherited bleeding disorder that has been seen in humans, dogs and cattle (Gentry, 1984). FXI is trace protein in the blood, it is produced in the liver and plays a role in the coagulation flow, the chain reaction that is set in motion when there is injury to blood vessel. It helps in the activation of Factor IX another blood protein important in the clotting process. Prolonged 
oozing of blood following dehorning and castration may also be observed. The prevalence of Factor XI is almost worldwide as many heterozygous and homozygous for recessive gene were detected in Holstein population. The molecular basis of this coagulopathy has been recognized in Holstein cattle as 76-bp insertion in coding region of FXI gene (Gurgul et al 2009). This disorder has an adverse impact on reproductive traits and udder health in cattle. Watanabe et al 2006 genotyped FXI deficiency in stunted Japanese black cattle and found homozygous recessive and heterozygous with different health problems like hypogenesis syndrome, neonatal weak calf syndrome, growth retardation.

The mutation at the particular gene locus causes the occurrence of genetic disorders. FXID is an autosomal recessive disorder that occurs due to the insertion of $76 \mathrm{bp}$ segment into the exon 12 of FXID gene of cattle present on chromosome 27. It causes distraction to the production of normal and functional protein for blood clotting. In the Factor XI deficiency disorder the blood clotting mechanism gets affected in the animal and once the injury happens, the continuous bleeding occurs resulting in loss of blood. Sometimes the blood also oozes out in milk, metritis and mastitis. The disorder reduces the reproductive performance and also decreases the resistance to pneumonia in cattle. This is directly related to the economy of the farmer. Therefore it is important to screen the animal for this genetic disorder.

\section{Materials and Methods}

The 50 Gaolao males were selected for present study. Randomly, the peripheral blood samples were collected from 50 male Gaolao bull from Wardha, Amarawati and Nagpur district of Vidarbha region of Maharashtra State. The blood samples $(5 \mathrm{ml})$ were collected in EDTA containing vacutainer from each Gaolao bull by jugular veinipuncture and transported and stored at $20^{\circ} \mathrm{C}$ at Genetic Investigation Laboratory, Mumbai Veterinary College Mumbai for maintaining the cold chain. The Genomic DNA was isolated from the blood samples by Phenol: Chloroform: Isoamyl: alcohol method described by (Sambrook et al., 1989). The quality and quantity of the DNA was checked by gel electrophoresis ( 0.5 per cent) and Nanodrop respectively. Good quality DNA showing the optical density ratio (260/280) between 1.8 to 2.0 was subjected for the PCR amplification and analysis. The primers used for the amplification of FXID were: FXIF: 5'CCCACTGGCTAGGAATCGTT3' FXIR: 5'CAAGGCAATGTCATATCCAC3'(Marro $\mathrm{n}$ et.al 2004). The PCR reaction was carried out with $25 \mu \mathrm{l}$ reaction mixture consisting, PCR master mix: $22 \mu 1$, Forward primer: 0.5 $\mu 1$, Reverse primer $0.5 \mu \mathrm{l}$, DNA sample: $1 \mu \mathrm{l}$ and distilled water: $1 \mu \mathrm{l}$ was prepared. Total $25 \mu \mathrm{l}$ PCR mixtures were made for each sample. The PCR was carried out by the protocol: Initial denaturation at $94^{\circ} \mathrm{C}$ of $2 \mathrm{~min}$ followed by 37 cycles of $94^{\circ} \mathrm{C}$ for $30 \mathrm{sec}$, annealing of primers at $60.4{ }^{\circ} \mathrm{C}$ for $1 \mathrm{~min}$ and extension at $72^{\circ} \mathrm{C}$ for $45 \mathrm{sec}$ followed by final extension at $72^{\circ} \mathrm{C}$ for $10 \mathrm{~min}$. The amplification the PCR products were electrophoresed in 1.7 per cent agarose stained with ethidium bromide using $100 \mathrm{bp}$ DNA ladder. The bands were visualized and documented using the gel documentation system.

\section{Results and Discussion}

Total 50 Gaolao males were screened for FXID gene by PCR. The amplification of FXID gene presented 244 bp bands for all the samples. As per Marron et al., (2004) the carrier animal will present two bands of 320 bp and $244 \mathrm{bp}$ size and the affected animal should present $320 \mathrm{bp}$ band. In the present 
study all animals showed a single band of the size $244 \mathrm{bp}$ indicating that all animals screened in this study have wild type FXI alleles (Fig. 1).

Fig.1 Agarose gel electrophoresis of the PCR amplified fragment of FXI gene

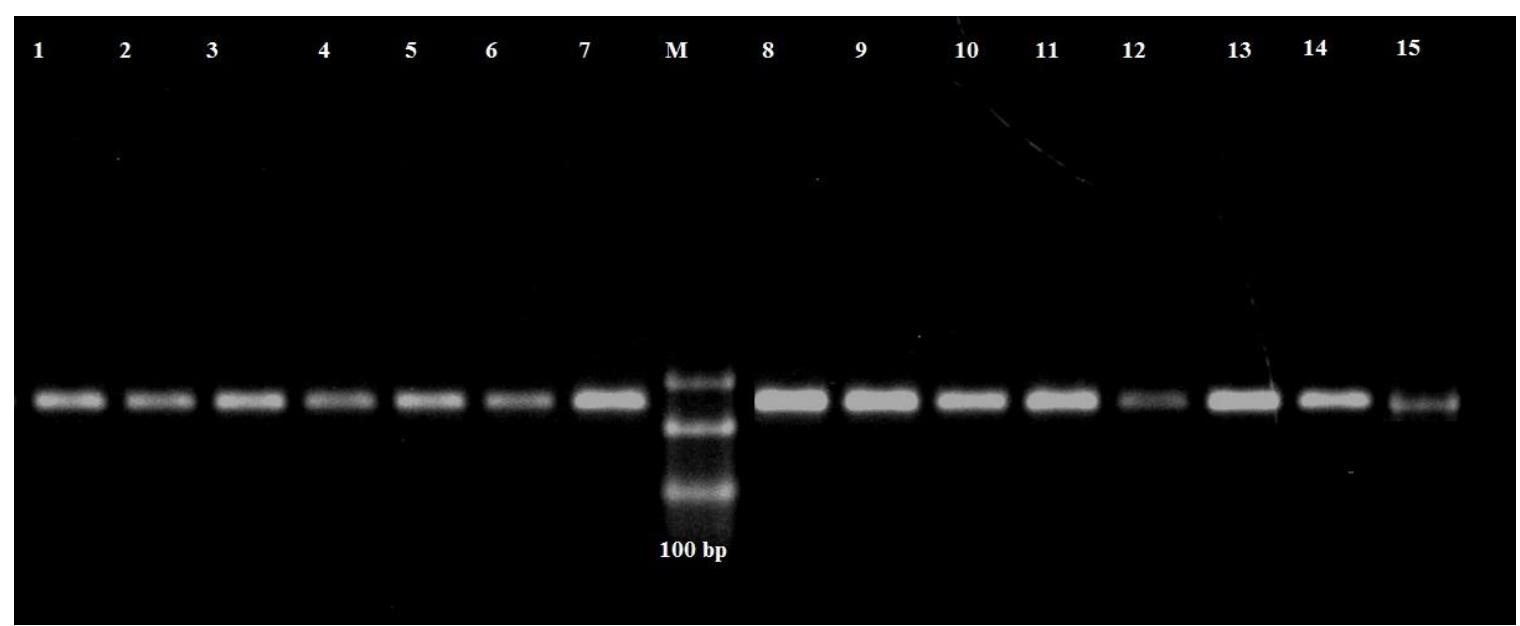

Lane 1to 7: 244 bp Lane M:100bp DNA ladder and Lane 8 to 15 :244 bp

Similar results were observed by Ramesha et al., (2017) in Murrah and Surti Buffalo from different state semen stations. Mukhopadhaya et al., (2006) also reported similar findings in 307 number of Indian Holstein cattle. Rajesh et al., (2007), Bagheri et al., (2012) and Saeed et al., (2012) also reported normal band patterns $244 \mathrm{bp}$ for the FXI in the animals screened. FXID was reported in Turkey in four animals for the first time out of total 225 Holstein cows screened (Meydan et al., (2009). However, Mondal et al., (2016) found the frequency of carrier and mutant allele as 2.5 and 0.025 respectively in Indian Sahiwal cattle. Akyuz (2013) detected 1.7 percent prevalence of FXID in Holstein bulls. Similarly Meydan et al., (2010) found $0.9 \%$ mutant allele and $1.8 \%$ heterozygous cows in the herd of 225 Turkesh Holstein cattle.

The present male Gaolao cattle population showed the presence of wild type of FXI allele. However, animals for this genetic disorder, more number of breeding animals should be screen to avoid the transfer of this genetic disease in the future generations.

\section{Acknowledgment}

I am thankful to DAHO, Wardha, Assistant Commissioner Pohara farm of Amarawati district, Regional manager FS lab Nagpur and Deputy director ILFC NVC, Nagpur, permitting for collection of blood samples and

\section{References}

Akyuz (2013) Determination of Allele Frequency of Factor XI deficiency (FXID) in Holstein Bulls Raised in Two Different Enterprise in Turkey. Kafkad Universitesi Veteriner Fakultesi Dergisi 19(1):127-131.

Hasan Meydan, M. A. Yildiz, F. Ozdil, Y. Gedik, F. Ozdil, Y. Gedik and G. Ozbeyaz (2009) Identiciation of Factor XI deficiency in Holstein cattle in Turkey. Acta Veterinaria Scandinavica, 51(5):1-4.

Gentry,P.A.(1984) The relationship between factor XI coagualant and factor XI antigen activity in cattle. $\mathrm{C}$ and $\mathrm{J}$. Comp. Medici.48:58-62

Gurgul A., Rubioe, D. and Slota E. (2009) 
Identification of carriers of the mutation causing coagualation factor XI deficiency in Polish Holstein-Friesian cattle. J.Appl.Genet. 50:149-152

Krishnedu Mondal, S. Chakravarti, A.K. Ghosh, S. Kumar, B. Naryak, S. Nandi, U. Sarkar, Rajib Deb, A. De, J. Biswas (2016) Novel identification of Factor XI deficiency in Indian Sahiwal (Bos indicus) cattle. Molecular Biology Reports, Vol 43 (4): 213-219.

Marron, B.M., J.L. Robinson and P.A. Gentry. 2004. Identification of a mutation associated with factor XI deficiency in Holstein cattle. Anim. Genet., 35: 454-456.

Meydan H. Yildiz M.A. and agerholm J.S. (2010). Screening for bovine leukocyte adhesion deficiency, deficiency of uridine monophosphate synthase, complex vertebral malformation, bovine citrullinaemia and factor XI deficiency in Holstein cows reared in Turkey.Acta Veterinaria Scandinavica.52:56

Mukhopadhyaya, P.N., Jha, M., Muraleedharan, P., Gupta, R.R., Rathod, R.N., Mehta, H.H., Khoda, V.K., (2006) Simulation of normal, carrier and affected controls for largescale genotyping of cattle for factor XI deficiency. Genetics \& Molecular Research 5: 323-332.
K.P. Ramesha, A. Rao., R. Alex, G.R. Geetha, M. Basavaraju, M.A. Kataktalware, D.N. Das and S. Jeyakumar (2017) Screening for Genetic disorders in Indian Murrah and Surti Buffalo (Bubalus bubalis) Bulls. Buffalo Bulletin. Vol 36(1): 133-142.

K.P. Rajesh, J.S. Kalpesh, B.C. Jenabhai, M.S. Krishna, R.S. Krothapalli and S. Rao (2007) Factor XI deficiency in Indian Bos taurus, Bos indicus, Bos taurus $\times$ Bos indicus crossbreds and Bubalis bubalis. Genet. Mol. Biol., 30(3): 580-583.

Saeed Bagheri, C. Amirinia, M. Chamani, M. Aminafshar, A. A. Sadeghi and H.R.Seyedabadi. (2012). Identification of Factor XI deficiency in Khuzestan Buffalo Population of Iran. Global Veterinaria 8(6): 598-600.

Vijay Kumar, Chandrashekhar S. Patil and Raghvendra Kumar Sharma. (2011). Bovine Factor deficiency: A Recessive Disorder in Holstein Friesian Cattle. Agri. Reviews, 32(3): 228-232.

Wantanabe D. Hirano, T. Sugimoto, Y. Ogata, Y. Abe S. Ando, T. Ohtsuka H. Kunieda, T and Kawamura S. (2006). Carrier rate of factor XI deficiency in stunted Japanese black cattle. J. Vet. Med. Sci. 68: 1251-1255.

\section{How to cite this article:}

Komatwar, S. J., R. J. Zende, B. N. Ramteke, S. H. Dalvi, R. S. Deshmukh and Sawane, M. P. 2021. Screening for FXI Deficiency (FXID) in Gaolao Cattle. Int.J.Curr.Microbiol.App.Sci. 10(01): 216-219. doi: https://doi.org/10.20546/ijcmas.2021.1001.026 